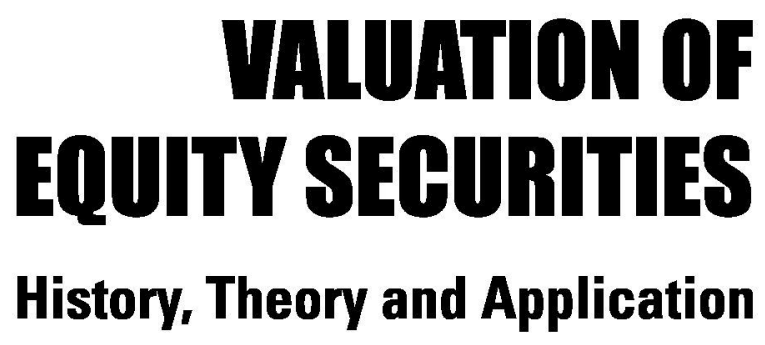




\section{VALUATION OF EQUITY SECURITIES}

History, Theory and Application

\section{Geoffrey Poitras}

Simon Fraser University, Canada 
Published by

World Scientific Publishing Co. Pte. Ltd.

5 Toh Tuck Link, Singapore 596224

USA office: 27 Warren Street, Suite 401-402, Hackensack, NJ 07601

UK office: 57 Shelton Street, Covent Garden, London WC2H 9HE

\section{British Library Cataloguing-in-Publication Data}

A catalogue record for this book is available from the British Library.

\section{VALUATION OF EQUITY SECURITIES \\ History, Theory and Application}

Copyright $@ 2011$ by World Scientific Publishing Co. Pte. Ltd.

All rights reserved. This book, or parts thereof, may not be reproduced in any form or by any means, electronic or mechanical, including photocopying, recording or any information storage and retrieval system now known or to be invented, without written permission from the Publisher.

For photocopying of material in this volume, please pay a copying fee through the Copyright Clearance Center, Inc., 222 Rosewood Drive, Danvers, MA 01923, USA. In this case permission to photocopy is not required from the publisher.

ISBN-13 978-981-4295-38-3

ISBN-10 981-4295-38-8

Typeset by Stallion Press

Email: enquiries@stallionpress.com

Printed in Singapore. 


\section{Preface}

This book contains many echoes of the project started in Security Analysis and Investment Strategy (Poitras 2005). Even though the road map is similar, Valuation of Equity Securities is a substantive step forward. The main difficulty confronted by Poitras (2005) was the treatment of both equity and fixed income securities under one cover that made it difficult to achieve an intellectually advanced treatment of securities valuation. While there are sound traditional reasons for combining the analysis of debt and equity securities - an approach going back at least to the so-called 'Bible of security analysis' (Graham and Dodd 1934) - the additional need for brevity meant valuable material had to be omitted to prevent the end product from resembling a big city phone book. Valuation of Equity Securities partially overcomes these difficulties by dropping the bulk of fixed income security valuation. Only basic theory of interest concepts, sufficient to execute discounted cash flow valuation, is examined. This permits attention to concentrate on the difficulties of estimating the future cash flows to equity, avoiding treatment of the subtleties in stochastic discounting techniques essential to advanced fixed income security valuation.

Another contrast between this book and Security Analysis and Investment Strategy is the influence of current events. Equity valuation is 'real time' and the method of incorporating changing information is integral to the valuation process. Poitras (2005) was influenced by the financial market debacles associated with the collapse of Enron and subsequent contagion engulfing Arthur Anderson, Worldcom, Adelphia, Global Crossing, and Tyco, to name only a few. Major investment banking institutions, such as Citigroup and JP Morgan Chase, were exposed for participating in the accounting shenanigans that hid the activities of Enron and others from the glare of public disclosure. Just as those events provided a useful backdrop for the arguments advanced in that book, Valuation of Equity Securities has been profoundly impacted by the events that began to unfold in early 2008, culminating into the most significant global financial collapse since 
the Great Depression. Though the substance of the arguments being made is largely independent of current events, considerable attention is given to grounding the arguments in a 'real-time' context.

While Poitras (2005) took rhetorical and critical aim at the limitations of the prevailing positivist philosophy that dominates both the instructional and research agenda of modern Finance, this book places emphasis on the implementation of valuation techniques. Instead of critiquing modern Finance, the argument is more focused on viewing Finance as a use-oriented subject, which needs to keep one eye squarely fixed on the needs of practitioners in the securities industry. When the theoretical ideas of modern Finance are explored in detail, the objective is not to demonstrate that the positivist approach is insufficient for dealing with the pervasive uncertainty in securities markets. Rather, the objective is to find the usefulness in the received theories of all components of Finance - old finance, modern Finance, and New Finance - for valuing equity securities. This complements the expanded examination of historical and philosophical aspects of the practical valuation problems encountered in the market for common stocks. Mantras such as 'stock returns outperform bond returns in the long run' and investment strategies derived from two-fund separation are examined in detail, with a view to extracting the insights for making equity valuation decisions.

Those aiming to use this book as the backbone of an advanced course on equity security analysis may be concerned that the philosophical explorations and some other topics lie too far outside the knowledge base of the typical advanced Finance student. Most such students have never taken a course on, say, the history of science or epistemology. Similarly, some of the mathematical content, such as the discussion of the stochastic differential equations associated with different specifications of the forward equation in Sec. 5.3, will be too technical for the typical Finance student. As a casual inspection of the book will reveal, such subsections form only a fraction of the book's content. Though this material is essential to developing key themes in the book, such as demonstrating how the ex ante/ex post biases in modern Finance can be theoretically resolved, the informational and practical content contained in the book can be readily digested without giving much consideration to these issues. A useful example of the type of non-philosophical and mathematical material in the book can be found in Part III, which deals with applications. It is difficult to conceive of a more practical application of equity security analysis than the real-time material and analysis contained in these chapters. 
The layering of material by sophistication level and analytical complexity makes the book suitable for a range of course levels and course content. Though there is some foundational material similar to what is contained in an introductory investments text such as Bodie et al.'s Investments, it is not pedagogically sensible to use this book as the core text in an introductory investments course. However, depending on instructor preferences, various chapters or subsections in Parts I and II could be used in such a course making the book suitable as a supplementary text and as a guide to a more advanced treatment of the subject. The practical material in Part III is, hopefully, within the grasp of students taking an introductory investments class. The bulk of advanced material in the book, with the exception of Chapter 5 , is targeted at courses in equity security analysis at the senior undergraduate and second year MBA level. If all advanced material is included, and the material in Part III is omitted, this book is also suitable for a $\mathrm{PhD}$ level course in equity valuation or financial statement analysis. The wealth of practitioner-oriented material also makes the book useful as, say, a supplementary text in trade courses or as a self-study guide for real-time equity security market combatants.

Those familiar with Poitras (2005) and two of my other books, The Early History of Financial Economics, 1478-1776 (2000) and Risk Management, Speculation and Derivative Securities (2002) may be concerned that this effort is, yet again, an example of the creeping incursion of typographical and editing errors in modern academic texts. For the sometimes annoying typos in my previous books, I apologize. Though there are no guarantees in life, rest assured that a herculean effort has been made to keep the bugs out of this effort. As with my previous books, the website at www.sfu.ca/ poitras will have posted an up-to-date listing of the typos and other errors that have been uncovered in this book. (In addition to containing errata lists for my previous books, the website also has a wealth of material on other subjects.) This book has benefitted considerably from the comments of anonymous and not-so-anonymous reviewers on preliminary drafts of the text. The risk of omission is such that I provide a global thank you to all who have participated in the review process. Feedback and discussion from numerous students over the years has also had a significant impact on the topic coverage. John Heaney contributed essential notions that appear in Chapter 5. At World Scientific Publishing, I would like to give special thanks to Lum Pui Yee and Alisha Nguyen. Without their efforts, this book would not have been produced. 


\section{Acknowledgments}

Though much of the material used in this book is from public sources, such as SEC filings, the preparation also required permission to reproduce copyright materials from journal articles, websites, newspapers, books, and magazines. The author and publisher gratefully acknowledge the permission from the following:

The American Economic Association (picture of Frank Knight on p.1)

The Graham Family (picture of Ben Graham on p.1)

The Wall Street Journal (Table 1.5)

The New York Stock Exchange Euronext (Fig. 1.2)

Journal of Economic Surveys (Tables 1.7-1.9)

Amsterdam History Museum (Fig. 2.2)

New York Historical Society (Fig. 2.7)

Berkshire Hathaway and Warren Buffett (Tables 3.1-3.3; picture on p.327)

Canadian Oil Sands Limited (Tables 4.1-4.3, Fig. 8.8)

Journal of Financial Economics (Fig. 4.4)

www.investorsintelligence.com (Fig. 6.1)

National Bureau of Economic Research (Table 7.1)

Stern Stewart, www.sternstewart.com (Table 7.8)

Professor Edward Altman (Tables 7.18-7.19)

British Petroleum (Table 8.1)

Graphs were also obtained from the internet financial news service www.globeinvestor.com 


\section{Contents}

\section{PART I: Philosophy, History, and Equity Securities}

1. The Philosophy of Equity Valuation 3

1.1 The Equity Security Landscape . . . . . . . . . . . . . . . 4

1.2 Risk, Return, and Uncertainty _. . . . . . . . . . . 43

1.3 Fact, Conjecture, and Rhetoric . . . . . . . . . 76

2. History of Equity Securities 97

2.1 Early History of Equity Security Markets . . . . . . . . . 98

2.2 Developments to Graham and Dodd (1934) . . . . . . . . 145

2.3 Derivative Security Renaissance . . . . . . . . . . . . . 186

3. Modern Equity Security Valuation 251

3.1 Foundations of Old Finance . . . . . . . . . . . . . . . 252

3.2 Value Stocks and Growth Stocks _. . . . . . . . . . 278

3.3 Modern Finance and New Finance . . . . . . . . . . . . . . . 301

\section{PART II: Theories of Equity Security Valuation}

4. Discounted Cash Flow Models 329

4.1 History of Equity Valuation Models . . . . . . . . . . . . 330

4.2 A Variety of DCF Models . . . . . . . . . . . . . . . . 342

4.3 Basic Theory of Interest . . . . . . . . . . . . . . 375

5. Stochastic Theories of Equity Value 389

$5.1 \quad$ Foundations of Modern Finance . . . . . . . . . . . . . . 390

$5.2 \quad$ Ergodicity and Asset Pricing Theories . . . . . . . . . . . 416

5.3 Bifurcation and Multimodal Densities . . . . . . . . . . 435

Appendix: Preliminaries and Proofs . . . . . . . . . . 456 
6. Technical Analysis Demystified 461

6.1 What is Technical Analysis? . . . . . . . . . . . . . . . . . 462

6.2 Traditional Technical Analysis . . . . . . . . . . . . . . 483

6.3 Recent Developments in Technical Modeling . . . . . . . . . . 514

Appendix: The Story of Richard Hanks . . . . . . . . . . . . . 527

\section{PART III: Fundamental Analysis and Equity Valuation}

7. Fundamental Analysis for Equity Securities 533

7.1 What is Fundamental Analysis? . . . . . . . . . . . . . 534

7.2 Interpreting Financial Statements . . . . . . . . . . . . . 561

7.3 Accounting, Legal, and Other Issues . . . . . . . . . . . . 612

8. Resource Companies: Oil Sands Producers 639

8.1 The Oil Sands and the Syncrude Project . . . . . . . . . . . . 640

8.2 Investment in Off-Shore Companies . . . . . . . . . . . . . . 659

8.3 Fundamental Valuation $\ldots \ldots \ldots$. . . . . . . . 677

$\begin{array}{ll}\text { References } & 701\end{array}$

$\begin{array}{ll}\text { Index } & 741\end{array}$ 